\title{
PATOGENESIS OF PIPE-STEM FIBROSIS OF THE LIVER (EXPERIMENTAL OBSERVATION ON MURINE SCHISTOSOMIASIS)
}

\author{
ZILTON A. ANDRADE \\ Centro de Pesquisas Gonçalo Moniz - FIOCRUZ, Rua Valdemar Falcão 121, Brotas, 41945 Salvador, BA, Brasil
}

Mice infected with 30 cercariae of Schistosoma mansoni developed portal and septal fibrosis due to the massive and concentrated deposition of eggs in the periportal areas which occurred following the 16 th week after infection. The lesion resembled pipe-stem fibrosis seen in human hepatosplenic schistosomiasis in the following characters: portal fibrosis interconnecting portal spaces as well as portal spaces and central canals; portal inflammation; periovular granulomas; vascular obstruction and telangiectasia. The liver parenchyma maintained its normal architecture.

Vascular injection techniques with Indian ink and vinylite revealed that the portal system developped numerous dilated collateral venules coming from the large and medium-sized portal branches, about 10 weeks after schistosome infection. The lodging of schistosome eggs into these collaterals resulted in granulomatous inflammation and fibrosis along all the portal tracts, thus forming the pipe-stem lesion.

Although not readily demonstrable grossly, the pipe-stem fibrosis of murine schistosomiasis has many similarities with the human lesion and can be considered to have the same basic pathogenesis.

Key words: schistosomiasis - pipe-stem fibrosis - pathogenesis

Pipe-stem fibrosis of the liver, as described by Symmers (1904), is a characteristic patholo. gical lesion of hepatosplenic schistosomiasis. It consists of generalized portal fibrosis with in trahe patic changes in the portal vein branches and radicles, and variable degree of telangiectasia (Bogliolo, 1957).

According to Lichtenberg \& Sadun (1968) the accurate characterization of pipe-stem fibrosis should include: 1) grossly evident, diffuse, stellate fibrosis and enlargement of the large and medium-sized portal fields; 2 ) variable portal inflammatory infiltration and crowding of the portal areas with schistosome eggs and granulomas (active stage) or with scar tissue containing egg shells and pigment (late stage); 3 ) conservation of the lobular architecture except for porto-central fibrous banding or post-necrotic scarring, usually confined to the subcapsular parenchyma; 4) relatively normal hepatocytic structure and function; 5) destructive lesions of the intrahepatic portal radicles. These authors conclude that taken together these features are virtually pathognomonic of pipe-stem fibrosis on gross examination.

A well developed, grossly demonstrable fibrotic lesion has been experimentally reproduced in chimpanzees heavily infected with either $S$. japonicum (Lichtenberg et al., 1971) or S. mansoni (Sadun et al., 1970). Warren (1966) obtained comparable microscopic lesion

Supported by FINHP (Grant no. 2541/85).

Received October 3, 1986.

Accepted December 4, 1986. in mice with prolonged, mild $S$. mansoni infection and concluded that the bands of fibrous tissue located in the portal spaces were derived from the fusion of many granulomas. In that paper, Warren not only showed that clear-cut pipe-stem fibrosis could be produced in the mouse, but demonstrated that the schistosome eggs are the main pathogenetic factor responsible for such lesion.

However, the pathogenesis of pipe-stem fibrosis was not completly explained, since the reason why the schistosomose eggs were capriciously distributed along the portal spaces remained to be elucidated.

Data obtained in our laboratory from different experiments and at different times, regarding the pathology of experimental murine schistosomiasis, when analysed retrospectivelly seemed to produce the required data to complete the information on the pathogenesis of pipe-stem fibrosis of the liver.

In the present paper, we re-analysed that available material in an attempt to demonstrate the important vascular changes which appear responsible for the concentrated deposition of schistosome eggs all along the intrahepatic portal area and to try to characterize the main histological features of murine pipe-stem fibrosis.

\section{MATERIAL AND METHODS}

Albino Swiss mice of both sexes, weighting 18-24 grams, were infected with 30 recently shed cercariae of the Feira de Santana strain 
(Andrade \& Sadigursky, 1985) of Schistosoma mansoni, by the percutaneous route. Animals eliminating viable $S$. mansoni eggs in the stools were killed at $8,10,16,20,25$ and 30 weeks after infection. To evaluate the degree of infection the animals were perfused following the Duval and De Witt's method (1967) and had portions of their liver digested in $0,5 \% \mathrm{NaOH}$ for the counting of eggs according to Cheever (1968).

Fragments of the liver were fixed in neutral buffered formalin and also in Bouin's fluid. The material was embedded in paraffin and the sections stained with hematoxylin and eosin, Gomori's silver method for reticulum and the picrosirius-red method for collagen (Junqueira et al., 1969).

Some animals killed at 8 and 10 weeks after infection had their portal vein system injected in situ with concentrated India ink, until the surface of the liver turned a little dark. The whole liver was then fixed in formalin and dehydrated through several changes of absolute alcohol. After clarification in xylol, the injected liver could be examined under a stereoscopic microscope by transillumination.

Other animals from the same groups as above had their portal system injected with a 16 per cent solution of vinyl acetate in dehydrated acetone, with pressure not recorded. After injecin situ with concentrated India ink, until the liver was kept in water for $24-48$ hours. The organ was then submitted to digestion in concentrated hydrochloric acid for $24-48$ hours, after which the plastic cast was recovered, washed in water and alcohol, dried and examined grossly and under a dissecting microscope.

Animals with 8,10 and 20 week old infection were submited to curative treatment with hycanthone $(80 \mathrm{mg} / \mathrm{kg}$. body weight, by in tramuscular injection) and oxamniquine (100 $\mathrm{mg} /$ $\mathrm{kg}$ body weight, given by gastric tube), simultaneously. Cure-rate was 100 per cent as seen after perfusion. Animals were killed at several different intervals after treatment, from the second day up to $4 \frac{1}{2}$ months, always toge ther with an untreated control. Infection yielded 3-5 pairs of worms per mouse and the egg counting after 16-25 weeks of infection gave an average of 5000 eggs per gram of liver tissue.

Part of the material now analysed has been used in a previous publication (Andrade \& $\mathrm{Bri}$ to, 1981), but the major part of it is from work still in progress.

\section{RESULTS}

Sequential analysis of the histological sections showed that the scattered periovolar gra- nulomas formed in the hepatic tissue during early infection ( 8.10 weeks), started to become concentrated within the portal spaces by the $16^{\text {th }}$ weck of infection. When isolated within the hepatic tissue the periovular granulomas formed discrete foci of fibrosis, which tended to undergo gradual resorption with time. In the portal spaces, the granuloma apparently tended to be fused together and bands of fibrous tissue of variable thickness could be observed in the liver of animals sacrificed at/or after 16 weeks of infection.

The intraparenchymal granulomas continued to be observed up to $4 \frac{1}{2}$ months after infection, but after 16 th week from cercarial exposition the majority of granulomas appeared to be concentrated in the portal areas. The portal space were enlarged and formed strands of fibrous tissues that fanned out for variable distances into the parenchyma (Fig. 1) forming a stellate scar (Fig. 2). Some fibrous septa were seen bridging neighboring portal spaces as well as connecting portal spaces with central canals. Within the portal fibrous tissue focal proliferation of biliary ducts could be observed. The periportal fibrous tissue was represented mainly by collagen concentrically oriented around periovular granulomas, or forming a network of fibers, but some part of it contained packed parallel and long fibers which run outside the granulomas, while some granulomas appeared fused together (Fig. 3). The schistosome eggs deposited along the periportal areas presented variable aspects, some being still viable, but the majority appearing calcified, distorted or represented by the empty egg shell only. The portal spaces usually appeared diffusely infiltrated by mononuclear cells, especially macrophages, plasma cells and giant cells of the foreign body type formed around remnants of egg shells. Although no invasion of the hepatic cell limiting plate by the inflammatory cells was ever detected, such cells were usually more concen. trated in the vicinity of the parenchymal border.

Variable degree of telangiectasia could be noted in some periportal lesions (Fig. 4), represented by many thin-walled dilated blood vessels and probably lymphatics. Usually not only the portal spaces but the fibrous septa and bands originated from them disclosed a rich vascula. rization (Fig. 5). The larger portal veins presented sometimes fiorous replacement of the media and irregular, excentric fibrous thickening of the intima, which resulted in variable narrowing of the lumen. The lobular architecture of the parenchyma was maintained. Even when sulcated by fine and long septal fibrosis, the regular disposition of sinusoids and liver cell cords in the parenchyma did nct appear altered. 


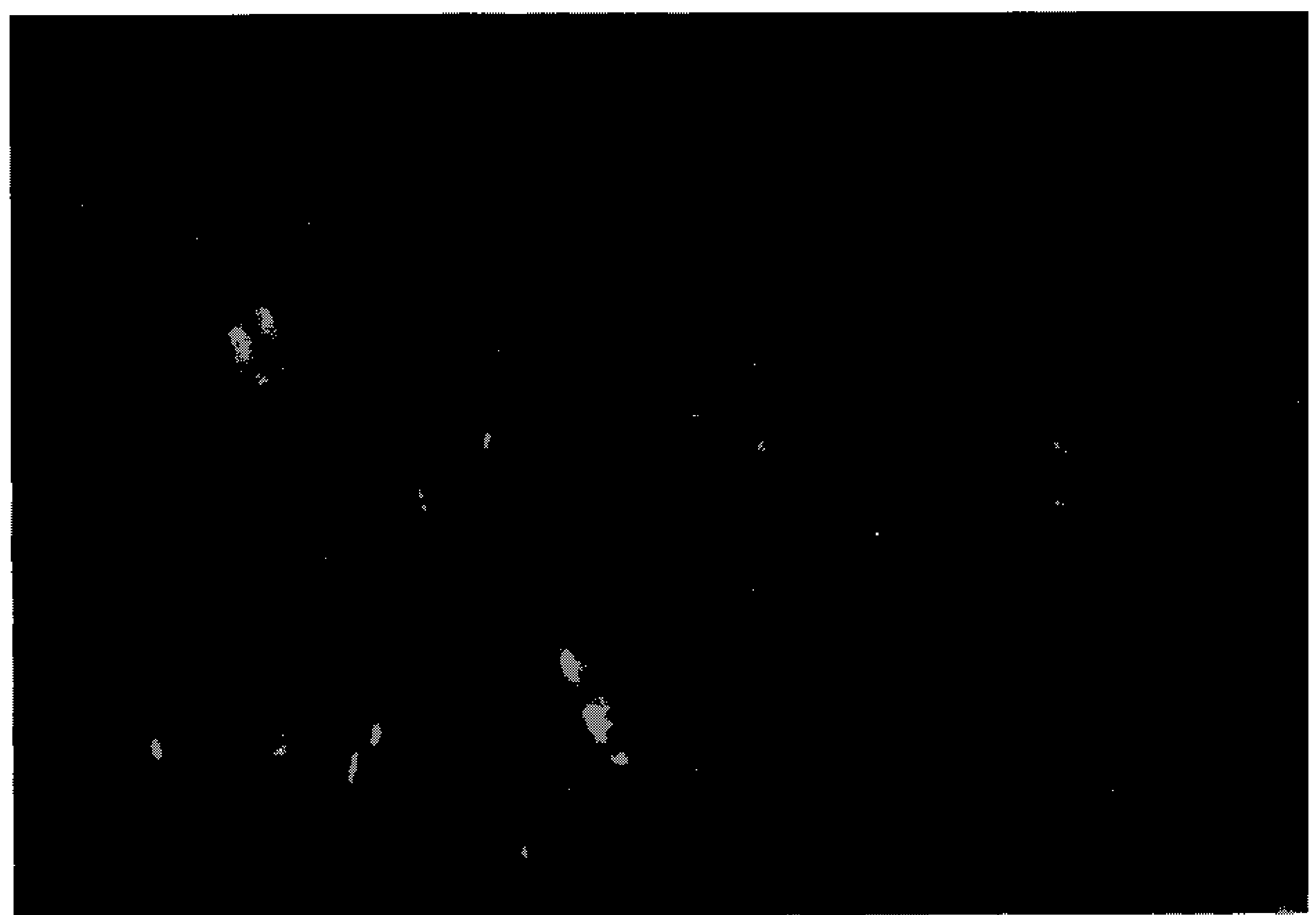

fig. 1: Low power picture showing portal and septal fibrosis in the liver of a mouse with a 20 -week old Schistosoma mansoni infection. There can be seen septal fibrosis connecting portal spaces with portal spaces as well as with central veins, while the parenchyma main tains its normal aspect. Picrosirius-red staining. X25.

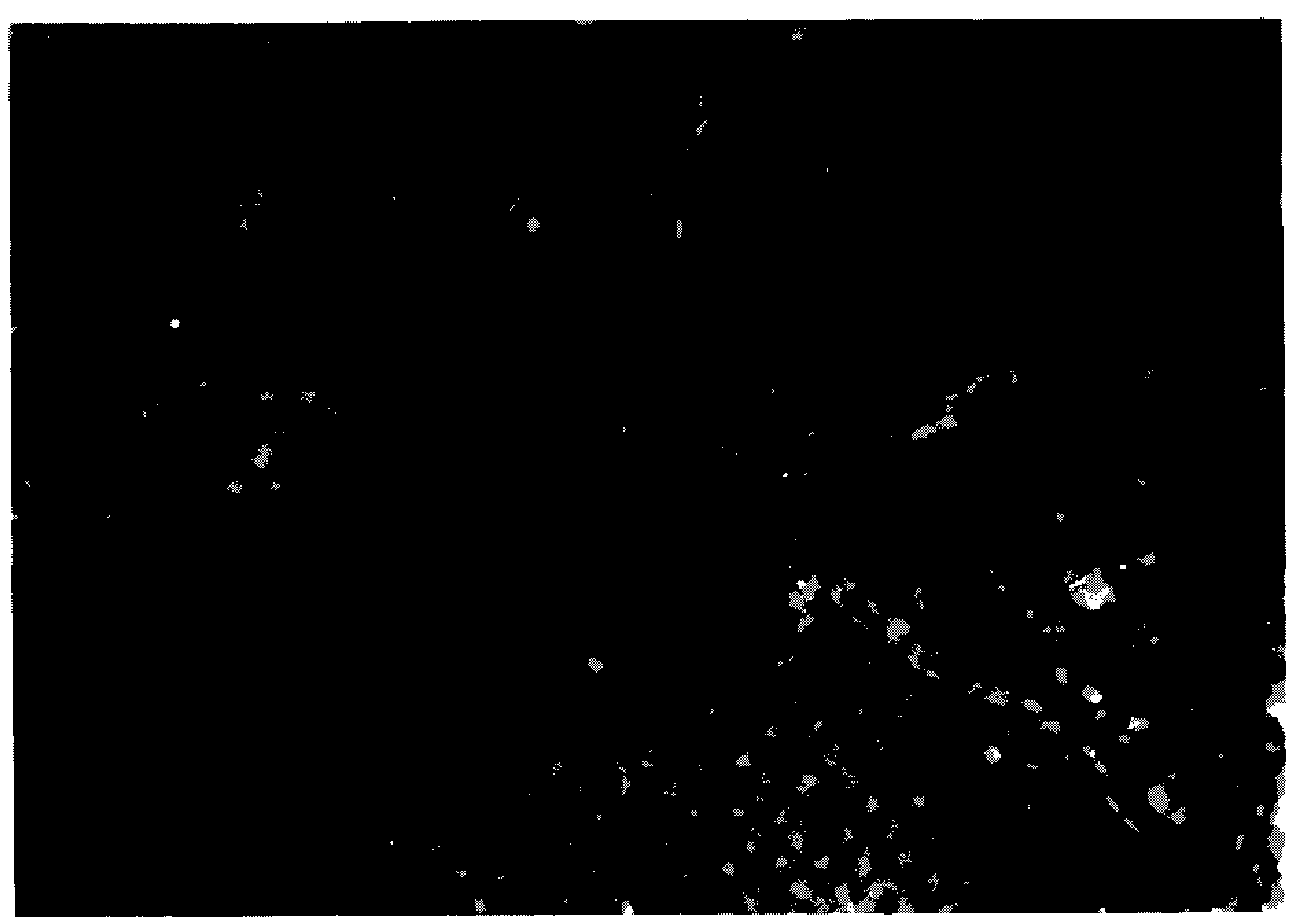

1:ig. 2: Stellate portal fibrosis centered by a large portal branch which reveals concentric collagenization of its wall (phlebosclerosis). The arrows point to a focal area of proliferation of biliary ducts. Picrosirius-red staining. X200. 


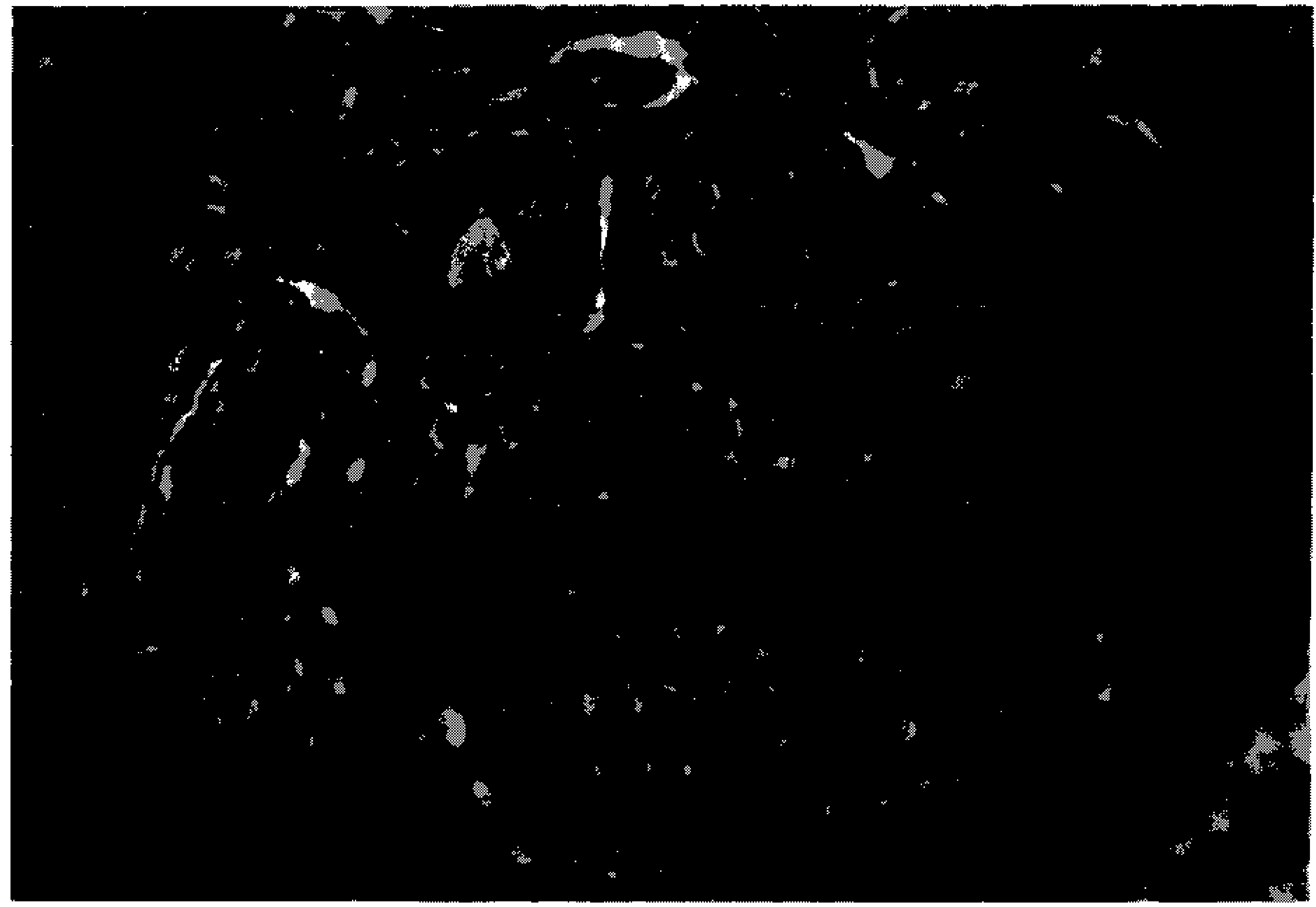

Fig. 3: Periovular granulomas being fused together within a portal space. Besides the collagens fibers concentrically oriented around the schistosome eggs, there are others disposed as a network or as parallel fibers which appear independently from the granulomas. Pictosirius-red staining. X200.

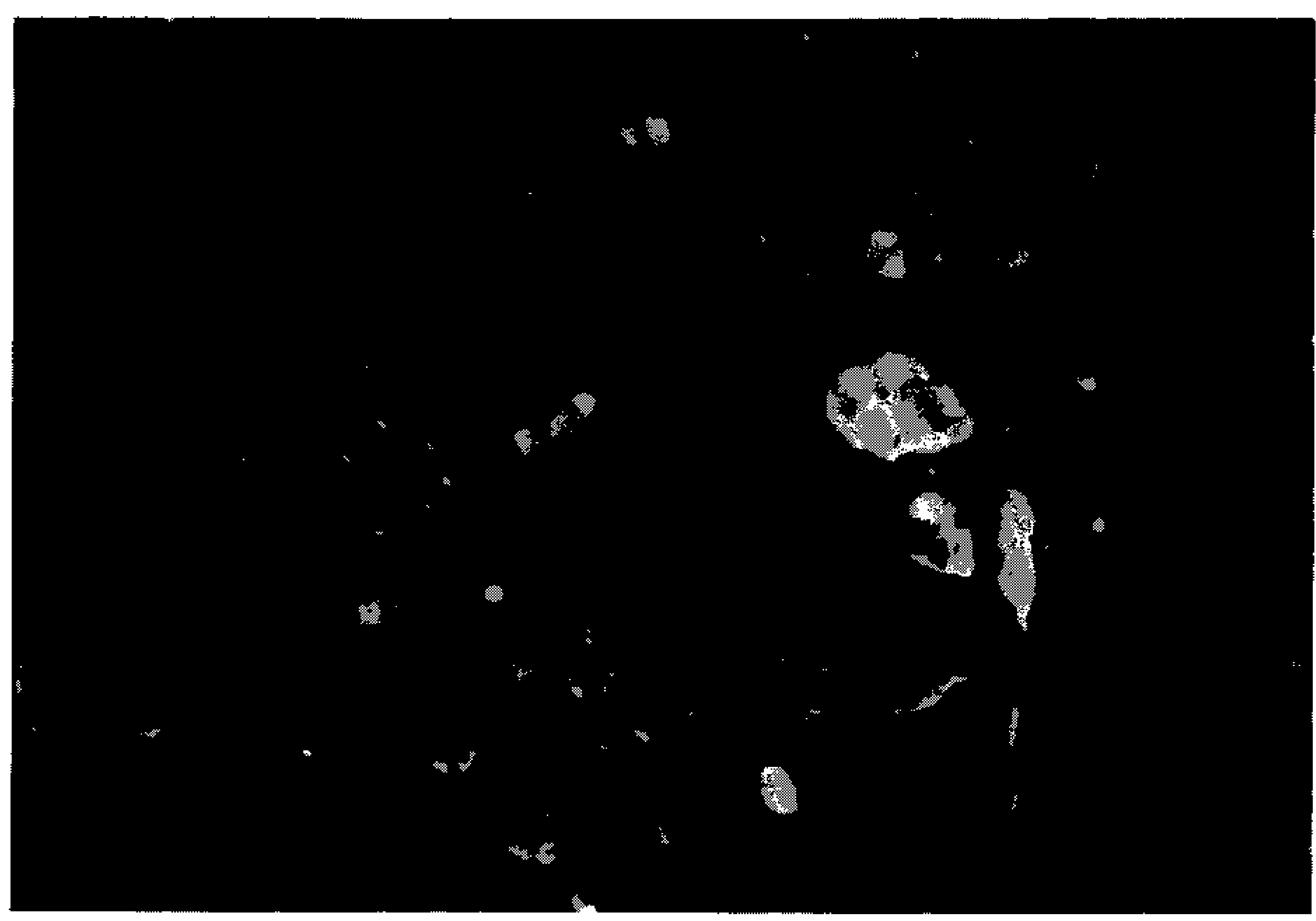

Fig. 4: Zone of portal fibrosis and telangiectasia, showing many thin-walled and dilated vessels and mononuclear inflammatory infiltration. The inflammatory œlls appear more concentrated at the limits between the portal space and parenchyma. Hematoxylin and Eosin. X150. 


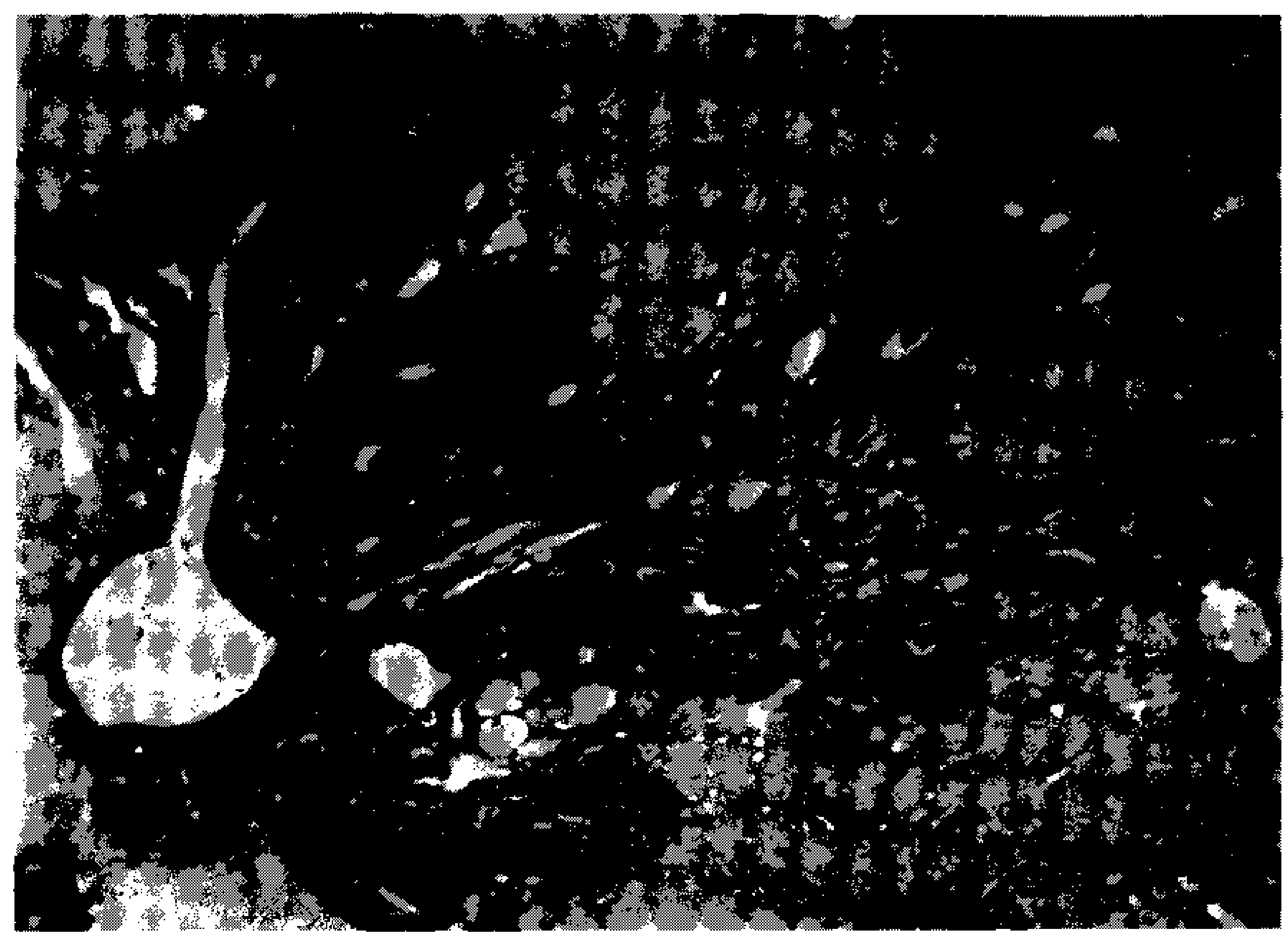

Fig. 5: A digitating portal scar tissue appearing with rich vascularization and dense collagen deposition in a mouse with a 25 -week old infection. Picrosirius-red staining. X100.

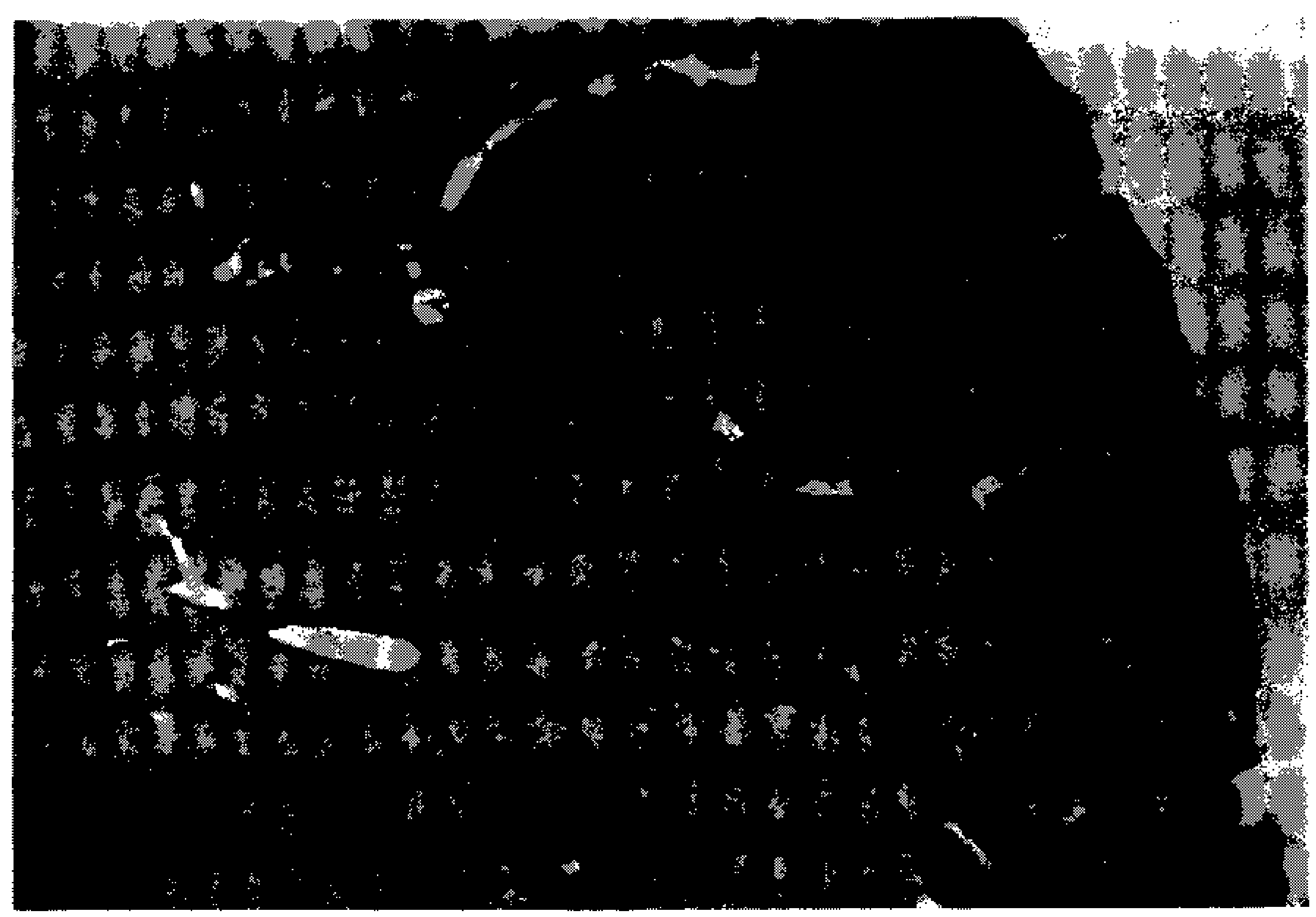

lig. 6: From a mouse subjected to curative treatment at the $20^{\text {th }}$ week after infection and examined 3 months afterward. Portal fibrosis has been considerably reduced and appears as fine tracts of collagen tissue on a clear parenchymal background. Pircrosirius staining. X50. 


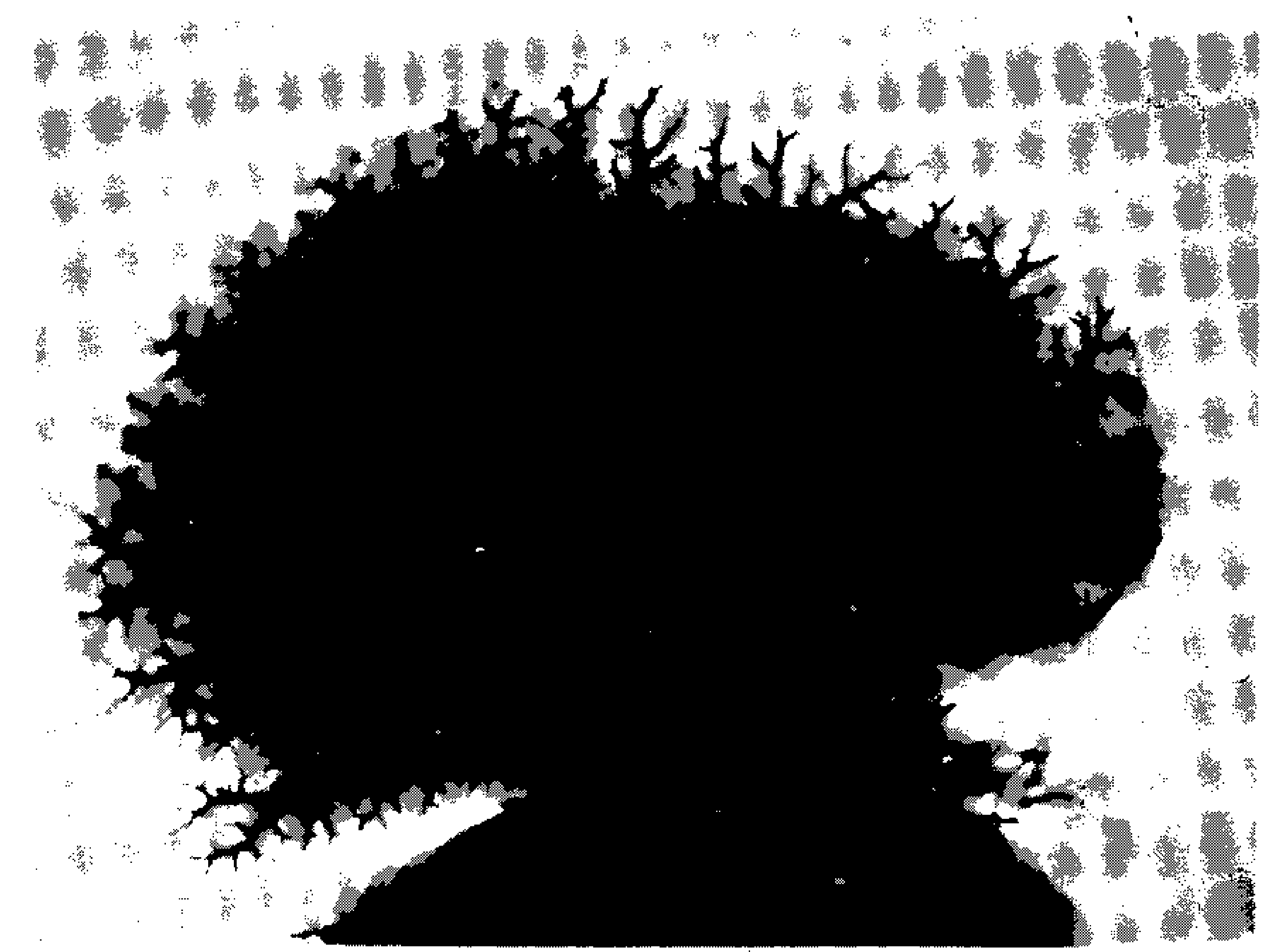

Fig. 7: Lobe of a normal mouse liver seen by transillumation after portal vein system had been injected with lndian ink. The normal vasculature stands out as delicate regular branching of vessels.

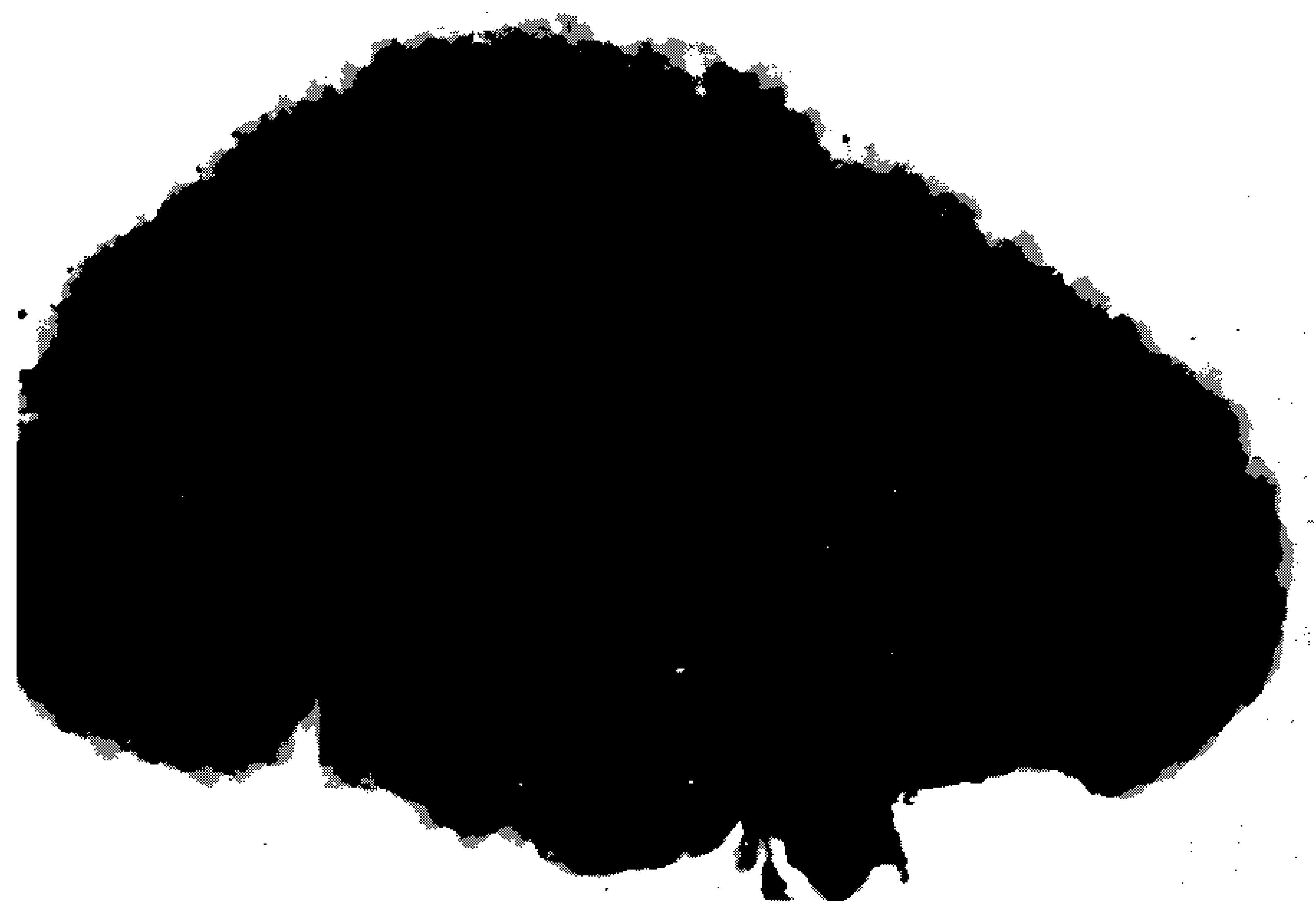

Fig. 8: The same technique used for the liver represented in Fig. 7 was applied to a liver of a mouse with a 10 -week old $S$. mansoni infection. The scape of the ink through the new developed portal collaterals directly into the sinusoids resulted in the diffuse blackening of the organ. Only at the periphery of the liver some distorted blood vessels can be observed. 


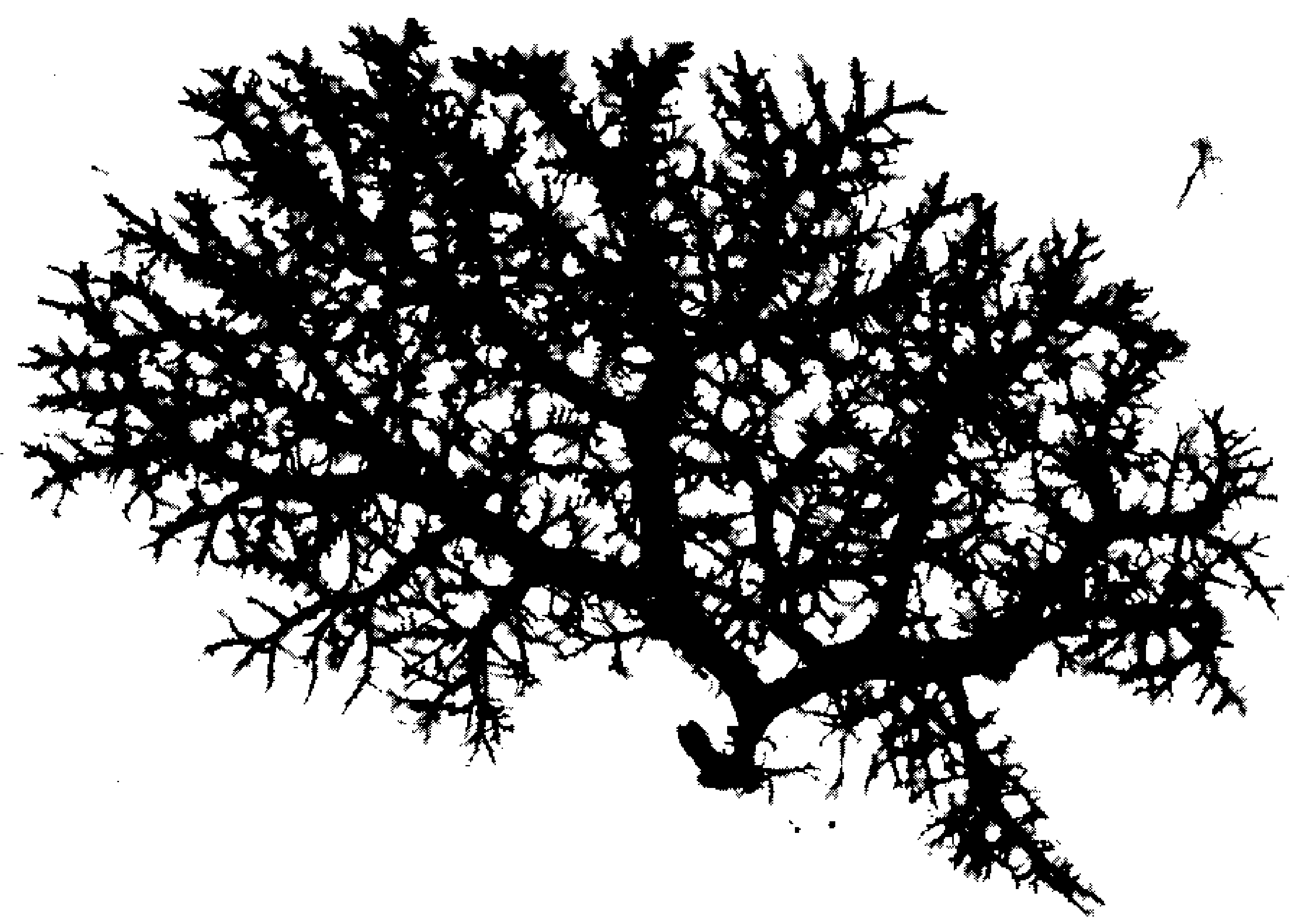

Fig. 9: Normal portal vein system of a mouse seen after vinylite injection-corrosion technique. The tree-like regular branching is evident.

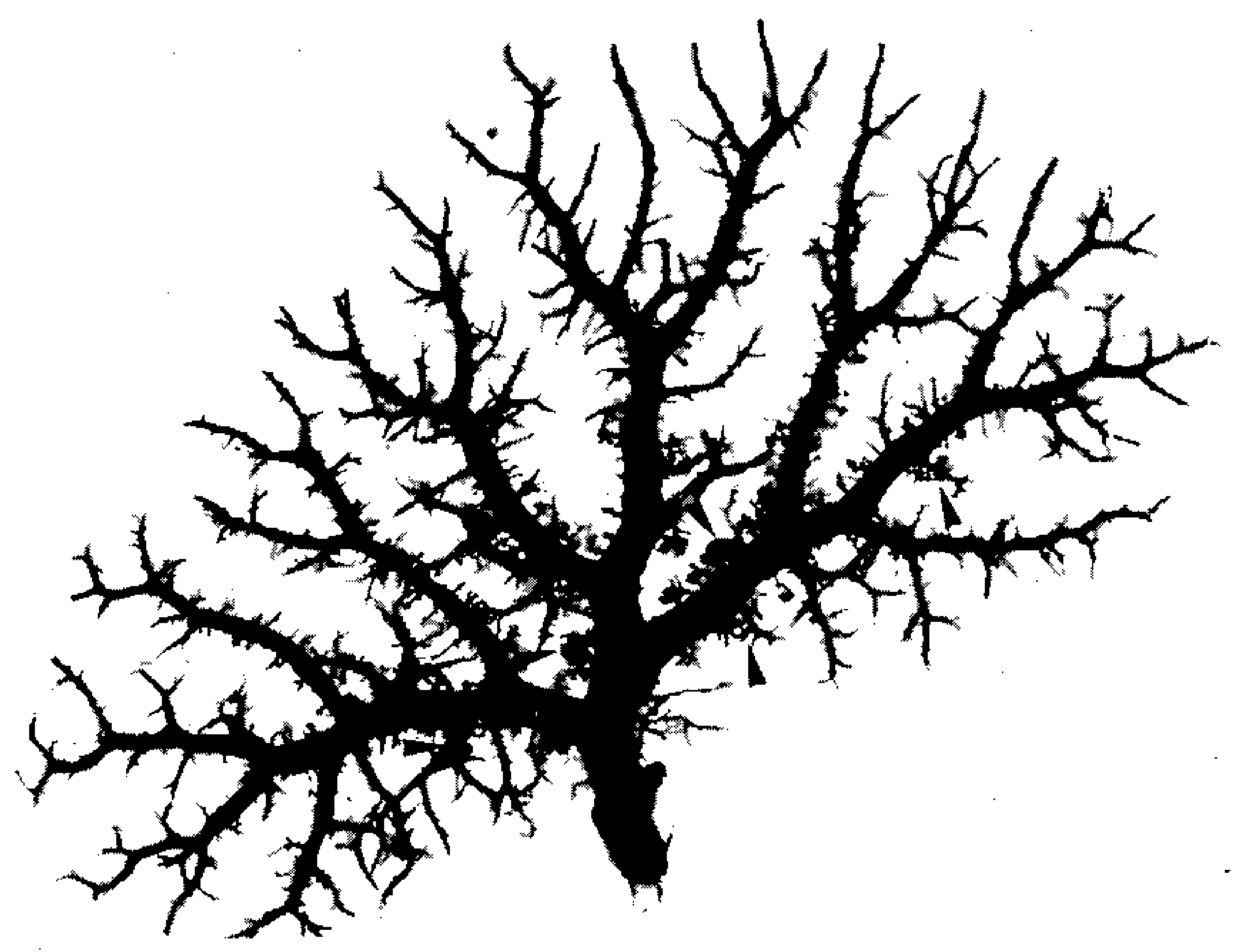

Fig. 10: Portal system of a mouse which has been infected with $S$. mansoni 10 weeks previously. The re is considerable amputation of the smallest peripheral portal branches. There are numerous thin collateral venules comming out from the large and medium-sized portal branches, some of them forming complex anastomoses amongst themselves (arrows). It is these vascular changes that allow the concentrated deposition of schistosome eggs along the periportal areas for the later development of pipe-stem fibrosis. Vinyl acetate injection followed by corrosion in hydrochloric acid. 
After cure of schistosomiasis the ccllagen in previovular granulomas, regardless of location, showed signs of resorption, the amount of fibers stainable by the picrosirius-red method diminishing considerably and appearing fragmented and with variable thickness as the time of observation following treatment was increased. Animals treated at the 20th week after infection when examined 3 months later (Fig. 6), presented only thin septa of fibrous tissue in the portal areas, sometimes connecting portal spaces, in clear contrast with the untreated controls. However, the disappearance of fibrous tissue in periportal areas was apparently slower and less complete when compared with that in the isolated previovular granulomas. The majority of the latter usually disappear completly four months after treatment, while the portal tissue remains as thin septa containing egg remnants and accumulated dark pigment.

The method of injecting India ink into the portal vessels to observe the liver through clarification and transillumination permitted a good assessment of the portal vasculature in the normal mouse (Fig. 7). The vessels showed its usual dichotomization, and this could be followed up to the finest portal branches, or even further up to the sinusoids.

In the infected mice, especially those with prolonged infection (10 weeks after infection on) the same method caused the instantaneous blackening of the whole liver, making impossible the recognition of the details of the portal vasculature (Fig. 8). Even when the precaution to inject only a small amount of ink was taken, the diffuse blackening occured.

The plastic casts obtained with vinylite disclosed the usual normal pattern when the portal system of a non-infected mouse was injected (Fig. 9). The plastic casts obtained from mice with 16 weeks old infection showed a considerable decrease of the finest portal branches at the periphery of the organ. In contrast there appeared many fine tugs comming out from the so-called conducting branches of the portal system, imparting a hairy appearance to this system (Fig. 10). All along the largest to the smallest portal vessels there emerged small inlets of collateral vessels, sometimes making anatomoses among themselves.

\section{COMMENTS}

This study demonstrates that in the course of murine schistosomiasis, the progressive blocking of the finest radicles of the portal system by embolizing eggs resulted in the dilatation of numerous thin collateral veins which originated from the large and medium-sized portal branches. By observing prolonged and relatively mild schistosome infection in the mouse, as did Warren (1966), it was possible to see the development of stellate portal fibrosis, when numerous eggs were entrapped in the small, but dilated, periportal collateral veins. It is however controversial whether the periportal fibrosis observed in mice with prolonged $S$. mansoni infection can be considered as a true counterpart of human pipe-stem fibrosis. Cheever (1965b) studied the development of schistosomiasis in different types of rodents and stated that the portal fibrosis observed in mice did not resemble the pipe-stem fibrosis of schistosomiasis in human being. Anatomically, the obstruction caused by the eggs seems to occur particularly in the short inlet venules, between the portal venules and the sinusoids and the resulting lesions is essentially different from pipe-stem fibrosis in human beings Cheever, 1965b).

Studying cases of human pipe-stem fibrosis of the liver, Andrade \& Cheever (1971) noticed that the sections of the portal vein in the larger portal spaces appeared dilated, whereas the portal vein branches in the smallest portal tracts were ocluded or had considerable narrowing of their lumina. The deduction was that the schistosomal lesions affected primarily the portal vein branches located at the hepatic periphery, which caliber permitted the schistosome eggs to be lodged during their displacement along with the portal blood flow. Probably, when the obstruction of these peripheral vessels was diffuse enough, increased intrahepatic blood pressure caused dilatation of the larger branches and helped to open the fine collateral veins originating at right angles from the larger portal ramifications, thus producing an angiomatoid appearance of the fibrosed portal spaces.

Vascular injection technique in human pipestem fibrosis (Bogliolo, 1957; Andrade \& Cheever, 1971) has demonstrated an intricate vascular network of fine collateral vessels forming a cuffing around the larger portal branches. The lesion here described for the mouse seems to have the same characteristics as that of human in its pathogenesis as well as in its pathological presentation. Of course it is not a grossly demonstrable lesion, but it is a periportal fibrosis, with vascular telangiectasia and obstruction and originates from the deposition of many schistosomes eggs. It is the result of a prolonged and heavy infection in the mouse, since an infection with a few worm-pairs can be considered heavy for such a small animal. Cheever (1969) has stressed that infections used in laboratory animals are extremely heavy. The heaviest infection reported in man at autopsy have seldon been greater than 5 worm-pairs per kilogram of body weight, whereas in mice the lightest infec- 
tions are in the order of 50 worm-pairs per kilogram of body weight.

Although the lesions appear similar in man and mouse, and this recognition is important for the future utilization of the model, there probably exist notable differences between such diverse hosts. The dynamics of collagen formation and degradation may be quite different, judging from the rapidity with which collagen can be removed from the schistosomal lesions in the mouse (Andrade \& Grimaud, 1986). Even when pipe-stem fibrosis is present, as happened during this investigation, the degradation of collagen occurs to a great extend three months after the cure of schistosomiasis. The present findings suggest that periportal fibrosis in murine schistosomiasis is a quite reversible change, contrary to previous observation of Warren \& Klein (1969). The rapid turnover of collagen tissue in the murine liver may explain why accumulation of fibrous tissue in the pipestem fibrosis of mouse does not reach the density and the amount which can usually be observed in human lesions. The peculiar distribution of the portal vessels just before their communication with the sinusoids is another important point of difference between the hepatic structure of man and the mouse (Cheever, 1965a). Also, the long, thin, digitating septal fibrosis so frequently seen in human pipestem fibrosis, does not appear as proeminently in the murine lesion.

However, in spite of the differences there are, on the other hand, many fundamental similarities between the schistosomal pipe-stem fibrosis in humans and in mice. Basic changes are commonly seen in both hosts: periportal fibrous enlargement, accumulation of periovular granulomas at several stages of evolution, vascular obstruction, telangiectasia, fibrous bridging between portal spaces and a normal looking parenchyma on the background. Besides, a clinical syndrome of hepatosplenic disease can develop as well during murine schistosomiasis (Warten, 1968).

\section{RJ:SUMO}

Patogenia da fibrose "pipe-stem" do f́́gado (observações experimentais na esquistossomose murina) - Camundongos infectados com 30 cercárias do Schistosoma mansoni desenvolveram fibrose porta em virtude de um depósito progressivo e concentrado de ovos na região periportal. o que aconteceu a partir da 16 a semana da infecção. Esta fibrose tinha certas características da chamada fibrose "pipe-stem" do homem vista na forma hepatoesplênica da esquistossomose, tais como obstrução das radiculas porta, telangiectasia, conexão fibrosa en- tre espaços porta e entre estes e veias centrais, além de certo grau de fibrose septal, presença dos granulomas em várias fases evolutivas e reação inflamatória crônica difusa, enquanto o parênquima hepático mantinha a sua estrutura lobular normal.

As técnicas de injeção vascular com tinta da China e com vinilite feitas no sistema porta permitiram a elucidação do mecanismo da concentração de ovos (e conseqüentemente da fibrose) nos espaços porta. Observou-se que após certo tempo da infeç̧ão, abrem-se colaterais que saem diretamente em ângulo reto dos principais ramos porta. Após a 16a semana de infecção em diante, os ovos tendem a se depositar nestas colaterais, ao invés de se distribuírem difusamente nos finos ramos terminais como acontece antes deste período. A fibrose "pipe-stem" do camundongo tem muitas semelhanças com a lesāo humana, embora não seja facilmente demonstrável macroscopicamente, tudo indicando que se desenvolva na base de uma mesma patogenia.

$$
\begin{aligned}
& \text { Palavras-chave: esquistossomose - fibrose "pipe- } \\
& \text { stem" - patogenia }
\end{aligned}
$$

\section{REFERENCES}

ANDRADE, Z.A. \& BRITO, P.A., 1981. Evolution of schistosomal hepatic vascular lesions after specific chemotherapy. Am. J. Trop. Med. Hyg., 30 :12231227.

ANDRADE, Z.A. \& CHEEVER, A.S., 1971. Alterations of the intrahepatic vasculature in hepatosplenic schistosomiasis mansoni. Am. J. Trop. Med. Hyg., $20: 425-432$.

ANDRADE, Z.A. \& GRIMAUD, J.A., 1986. Evolution of the schistosomal hepatic lesions in mice after curative chemotherapy. Am. J. Pathol, 124 :59-65.

ANDRADE, Z.A. \& SADIGURSKY, M., 1985. Um estudo comparativo das cepas Feira de Santana (Bahia) e Porto Rico do Schistosome mansoni na infecçāo experimental do camundongo. Mem. Inst. Oswaldo Cruz, 80:37-40.

BOGLIOLO, L., 1957. The anatomical picture of the liver in hepatosplenic schistosomiasis mansonı. $\mathrm{Am}$. Trop. Med. Parasitol, 51 :1-14.

CHEEVER, A.W., 1965a. A comparative study of Schistosoma mansoni infections in mice, gerbils, multimammate rats and hamsters. I-The relationship of portal hypertension to size of hepatic granulomas. Am. J. Trop. Med. Hyg., 14 :211-226.

CHEEVER, A.W., 1965b. A comparative study of Schistosoma mansoni infections in mice, gerbils, multimammate rats and hamsters. II-Qualitative pathological differences. Am. J. Trop. Med. Hyg., $14: 227-238$.

CHEEVER, A.W., 1968. Condictions affecting the accuracy of potassium hydroxide digestion technique for counting Schistosoma mansoni eggs in tissues. Bull. WHO, $39: 328-331$. 
CHEEVER, A.W., 1969. Quantitative comparison of the intensity of Schistosome mansoni infections in man and experimental animals. Trans. $R$. Soc. $\mathrm{Med}$. Hyg., $63: 781-795$.

DUVALL, R.H. \& DE WITT, W., 1967. An improved perfusion technique for recovering adult schistosomes from laboratory animals. Am. J. Trop. Med. Hyg., $16: 483.486$.

JUNQUEIRA, L.C.U.; BIGNOLAS, G. \& BRENTANI, R., 1979. Picrosirius staining plus polarization microscopy, a specific method for collagen detection in tissue sections. Histoch. J., $11: 447-455$.

LICHTENBERG, F. \& SADUN, E.H., 1968. Experimental production of bilharzial pipe-stem fibrosis in the chimpanzee. Exp. Parasitol., 22 :264-278.

LICHTENBERG, F.; SADUN, E.H.; CHEEVER, A.W.; ERICKSON, D.G.; JOHNSON, A.J. \& BOYCE, H.W., 1971. Experimental infection with Schistosoma japonicum in chimpanzees. Parasitologic, cljnical, sorologic and pathological observations. $A m$. J. Trop. Med. Hyg., $20: 850-893$.
SADUN, E.H.; LICHTENBERG, F.; CHEEVER, A.W. \& ERICKSON, D.G., 1970. Schistosomiasis mansoni in the chimpanzee. The natural history of chronic infections after single and multiple exposures. Am. J. Trop. Med. Hyg., $19: 258-277$.

SYMMERS, W.St.C., 1904. Note on a new form of liver cirrhosis due to the presence of the ova of Bilharzia haematobia. J. Pathol Bacteriol, $9: 237$ 239.

WARREN, K.S., 1966. The pathogenesis of "clay-pipe stem cirrhosis" in mice with chronic schistosomiasis mansoni, with a note on the longevity of the schistosomes. Am. J. Pathol, $49: 477-489$.

WARREN, K.S., 1968. Pathophysiology and pathogenesis of hepatosplenic schistosomiasis. Bull. $N Y$ Acad. Med., 44 :280-294.

WARREN, K. A. \& KLEIN, L., 1969. Chronic murine hepatosplenic schistosomiasis mansoni: relative irreversibility after treatment. Trans. $R$. Soc. Trop. Med. Hyg., 63 :333-337. 